\title{
Comparative advantage, economic structure and growth: The case of Senegal
}

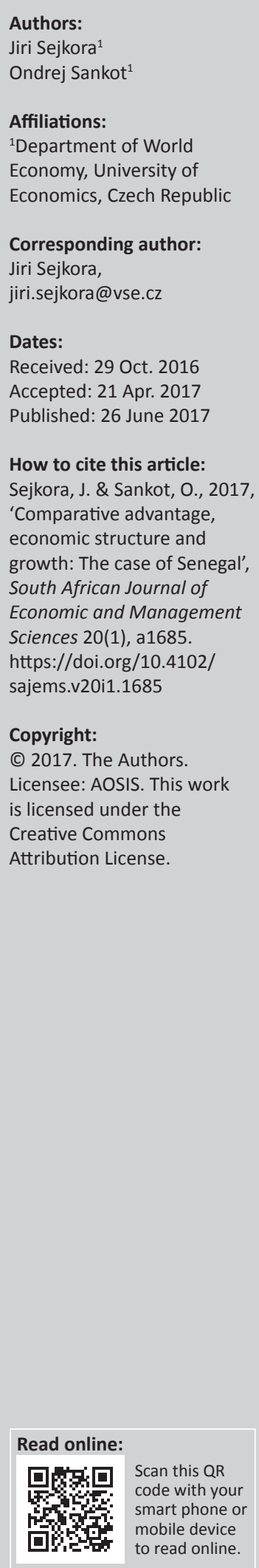

Background: Using a concept of revealed and latent comparative advantage, this article identifies relatively productive industries and industries with great potential in the slowgrowing economy of Senegal. The identification of such industries allows for economic structure adjustment resulting in a higher gross domestic product (GDP) growth rate.

Aim: The aim of the study is to identify Senegalese long-term revealed comparative advantages and to estimate Senegalese latent comparative advantages. The analysis is focused solely on manufacturing industries because industrialisation serves as an engine of growth in developing countries.

Setting: The analysis is carried out on endowment structure and international trade data (1995-2015) of Senegal and appropriate comparator economies (Tanzania, Cambodia, Lao, Vietnam and Cape Verde).

Methods: To identify revealed comparative advantages, we calculate the normalised revealed comparative advantage index. To estimate latent comparative advantages, we employ a growth identification and facilitation framework. The methodology is slightly modified because the estimation is based on long-term revealed comparative advantages comparisons (rather than export shares comparisons).

Results: We argue that the relatively productive manufacturing industries (with revealed comparative advantage) include chemicals and manufactured goods classified chiefly by various materials. Furthermore, Senegal may have unexploited potential (i.e. latent comparative advantage) in footwear and particularly in apparel production.

Conclusion: In order to accelerate GDP growth rate, Senegal should focus on developing the above mentioned industries to align its economic structure with the comparative advantages and also to promote industrialisation.

\section{Introduction}

Many sub-Saharan economies have been struggling to achieve and maintain high growth rates for a long period of time. For example, Senegal, a lower-middle income economy (according to World Bank [WB] criteria), grew at an annual average rate of 4.17\% between 1995 and 2015. At first glance the growth rate may seem acceptable; however, taking into account the modest level of Senegalese economic development and also demographics, we get a different picture. In per capita terms, the growth rate was only $1.33 \%$ (for the same period). ${ }^{1}$ Such a pace of progress may be perceived as unsatisfactory - from poverty alleviation efforts to middle class development, etc.

In this paper, we apply a concept of revealed and latent comparative advantage (LCA) to identify productive industries and industries with great potential in the Senegalese economy. Identification of those industries may help to adopt a comparative advantage following approach, as Lin (2012) puts it, which basically means aligning an economic structure with comparative advantages to achieve a higher gross domestic product (GDP) growth rate. We are specifically interested in manufacturing industries because industrialisation (i.e. manufacturing sector expansion) serves as an engine of growth in developing countries. Indeed, Kaldor's engine of growth hypothesis claims that there exists a strong relation between the manufacturing sector output and GDP growth (Kaldor 1966, 1967). The validity of the hypothesis (for developing countries) has been reinforced by many empirical studies (e.g. Dong et al. 2013; Ibbih \& Gaiya 2013; Libanio \& Moro 2006; Wells \& Thirlwall 2003). Therefore, Senegal, as well as other developing countries, could benefit from developing its productive manufacturing industries.

1.Own calculations using WB (2017) database. 
Dedicated studies analysing Senegalese comparative advantages are rare. To our knowledge, there has been one dedicated study by Jabara and Thompson (1980) in which comparative advantages in the Senegalese agricultural sector have been analysed. There are, however, several studies with broader scope - for example, World Bank's InfoDev (2011) discusses possible comparative advantages in Senegalese horticulture and other agricultural subsectors. Yeats (1998) uses the revealed comparative advantage (RCA) index to calculate comparative advantages of Senegal and other African countries to draw conclusions about intra-African trade. Eifert et al. (2005) analyse comparative advantages of Senegal and other African countries using a combination of macro and micro data. This paper, however, is mainly focused on the concept of LCA, which is rather new. The author of this concept, Justin Y. Lin, published relevant papers only a few years ago (see e.g. Lin 2012; Lin \& Monga 2011; Lin \& Treichel 2011; Lin \& Xu 2015), which is the reason why we lack papers on Senegalese LCAs.

The presented analysis is carried out on official data available in UNCTAD (2017) and other databases - Penn World Tables (Feenstra et al. 2017) and World Bank's World Development Indicators (WB 2017). Even though the existing data for Senegal and other developing countries are poor, the analysis is primarily based on international trade data, which is generally better in quantity and also in quality.

The rest of the paper is organised as follows: Revealed comparative advantage measurement and Latent comparative advantage estimation sections describe general theoretical background and research methodology regarding RCA measurement (Revealed comparative advantage measurement section) and LCA estimation (Latent comparative advantage estimation section). Comparative advantages of the Senegal section presents results of the Senegalese comparative advantage analysis. Discussion: Some challenges in the Senegalese apparel industry section briefly discusses challenges in the Senegalese apparel industry, while the final section concludes.

\section{Revealed comparative advantage measurement}

The original Ricardian model (Ricardo 1815) explains international trade flows as a result of different factor endowments in each particular economy. Because labour productivity differs among particular economies, each economy could specialise itself on production of a good it manufactures relatively more efficiently and gains through goods exchange in an international market. Ricardo used in his model just two countries and two goods, however, and so the idea that international trade could identify sector(s), where a particular economy is relatively more productive, remains to be a part of overwhelming consensus (Irwin 1991).

In order to identify and quantify economy's comparative advantage, we have to determine the relation between economic conditions as a source of comparative advantage on the one side with usable and quantifiable indicators on the other side. This relation was described by Balance et al. (1987) and is indicated by the following diagram (Eqn 1):

$\mathrm{EC} \rightarrow \mathrm{CA} \rightarrow \mathrm{TPC} \rightarrow \mathrm{RCA}$

According to (1), economic conditions (EC) that vary across countries determine the international pattern of comparative advantage (CA), which lies under the pattern of international trade, production and consumption (TPC). The relationship between EC, CA and TPC can be understood as what the international trade theories have been trying to identify: what kind of economic conditions determine comparative advantage that makes the trade to take place, and how the trade is going to affect the economy. (Sanidas \& Shin 2010:2).

As long as we are not able to determine exact autarkic prices and autarkic production costs within an economy, we have to rely on available trade data from the past to identify RCA as a second best alternative. RCA describes the pattern of CA, which is based on TPC. In other words, CA determines TPC and available combinations of TPC are recorded by RCA (Sanidas \& Shin 2010; Vollrath 1991).

Furthermore, the original theory considers only a simplified $2 \times 2$ situation, where merely two countries trade with one another and the whole trade volume consists of two types of goods only. Because the current global economy is not that transparent and straightforward, some authors dispute the relation between CA and TPC in a multi-country and multi-commodity world (Drabicki \& Takayama 1979). This suggests, as Hillman (1980:315) notes, that the question of 'the degree of advantage exhibited by a particular country over various goods' or 'the degree of advantage exhibited by various countries with respect to a particular traded good' identified by RCA, remains.

To increase RCA's explanatory value, it should be supplemented with other data to distinguish whether the export volume is caused by a comparative advantage (CA) or not; government policies, especially, could alter a country's original CA as, for example, Clarida and Findlay (1992) suggest. However, RCA could still 'certainly be used for the descriptive purpose of identifying in which sectors a country exports more or less than average' (Deardorff 2011:32). Given that international trade conforms to CAs, a country, which exports more particular goods than benchmark, produces this good more efficiently and disposes of the CA in its production.

Despite the fact that RCA does not have to provide an accurate identification and quantification of the CA in its original terms, according to Balance et al. (1987), RCA as a post-trade indicator can identify much about underlying patterns of the CA. Deardorff (1980), who proved that there is a negative correlation between net exports and relative autarkic prices, also shares this belief. That is why Sanidas and Shin (2010) also consider RCA 'to deliver proper information with respect to comparative advantage' (Sanidas \& Shin 2010:11). 
There are as many indicators as there are combinations of post-trade variables that could measure RCA (Balance et al. 1987). This paper focuses on normalised revealed comparative advantage index (NI), which patterns on the more common Balassa's revealed comparative advantage index (BI). For further RCA indicators, see Balance et al. (1987), Memedovic (1994) or Vollrath (1991).

\section{Revealed comparative advantage: Balassa index (BI)}

The most common formula for RCA identification, described by Balassa (1965), concentrates on a country's relative export performance. BI compares a particular commodity's export share with its share in total world exports. The following formula (Eqn 2) holds:

$$
B I i j=\frac{\frac{X i j}{X i}}{\frac{X w j}{X w}}
$$

where $X i j$ stands for exports of commodity $j$ by country $i, X i$ stands for total export of country $i$, Xwj stands for world's exports of commodity $j$, whereas Xw represents the world's total exports:

$$
\begin{aligned}
& \text { A given country is considered to have comparative advantage } \\
& \text { (disadvantage) in commodity, when the commodity's exports } \\
& \text { market size of country in terms of its total national exports market } \\
& \text { size is greater (less) than the commodity`s world exports market } \\
& \text { size in terms of the world total exports market size, i.e. when is } \\
& \text { greater (less) than unity. (Sanidas \& Shin 2010:12). }
\end{aligned}
$$

Comparative advantage neutral point is reached when BI equals to one. In this case, the country has neither CA nor disadvantage.

$\mathrm{BI}$ is straightforward and easily applicable as export data are generally available and calculation is simple. However, the only information BI provides is whether a country enjoys a CA in a particular commodity, or not (Yeats 1985). Results of $\mathrm{BI}$ are incomparable across time and space, because of its asymmetry, as BI reaches values from one to infinity.

\section{Normalised revealed comparative advantage index (NI)}

In an effort to overcome the aforementioned shortcomings of BI, alternative indicators have been developed. Ideal alternative indicators should demonstrate four characteristics: (1) stable mean across time and space, (2) symmetry around mean or median, (3) independence of classification and (4) stable distribution across time and space (Hoen \& Oosterhaven 2006). In fact, we still do not have such a perfect indicator and, therefore, as Sanidas and Shin (2010:17) note: 'some researchers expressed RCA using a hypothetical state: they used a deviation of the actual data from the value that would have been in the comparative advantage neutral (CAN) point'. This approach is incorporated in normalised revealed comparative advantage index (NI), calculated according to Yu et al. (2009) by the following formula (Eqn 3):

$$
N I i j=\frac{X i j}{X w}-\frac{X w j * X i}{X w^{*} X w}
$$

where NI value falls in between -0.25 and 0.25 , while comparative advantage neutral point (export value expected in the CAN state) equals to 0 . Because normalisation proceeds by the total amount of the world export, NI value tends to be very small. As recommended by Yu et al. (2009), NI values in this paper will be scaled by 10000 . Normalised revealed comparative advantage index is perfectly comparable across time and space, and mean value and NI sum remain stable.

This explains well the notion of zero sum imbedded in comparative advantage: if a country gains comparative advantage in one sector, then the country loses comparative advantage in other sectors; and if one country gains comparative advantage in a sector, then other countries lose comparative advantage in the sector. (Sanidas \& Shin 2010:18)

Normalised revealed comparative advantage index is capable of comparing the size of the CA in time, across sectors and also among economies. This is why NI is used in this paper.

\section{Latent comparative advantage estimation}

The concept of LCA is based on the aforementioned original Ricardian theory, which is at the centre of a relatively young neoclassical theory of New Structural Economics (NSE) (Lin 2012). The term refers to the classical CA which is, however, not being exploited. Therefore, LCA merely represents a potentially productive industry of an economy. In addition, because LCA is not being exploited, entrepreneurs, government and other subjects may not even be aware of its existence. For these reasons, it is obviously impossible to measure LCA in the way presented in the RCA measurement section. However, according to Lin (2012), it is theoretically possible to estimate the LCA of a particular economy by comparing its commodity export structure with other appropriate comparator economies.

Lin uses a structuralist approach to explain economic growth and development. NSE is built around Kuznets' (1966) notion that structural change is needed to achieve sustained economic growth. Lin (2012) argues:

\footnotetext{
...the main feature of modern economic development is continuous technological innovation and structural change. The optimal industrial structure in an economy, that is, the industrial structure that will make the economy most competitive domestically and internationally at any specific time, is endogenous to its comparative advantage, which in turn is determined by the given endowment structure of the economy at that time. (pp. 98-99)
}

The endowment structure (ES) is, therefore, crucial because it determines the CA and, consequently, the optimal industrial structure (OIS), as indicated by the following equation (Eqn 4):

$\mathrm{ES} \rightarrow \mathrm{CA} \rightarrow \mathrm{OIS}$

[Eqn 4] 
Equation 4 implies that two economies with similar ESs should have similar CAs. Therefore, as was already mentioned, it is possible to estimate LCA using a comparative method.

The ES (comprised of labour, natural resources and capital both human and physical) and thus the CA are dynamic in time. According to Lin (2012:307): ' ... the alignment of industry and/or technology with an economy's CA is key ... to accelerating the rate of economic growth and to realizing convergence'. This alignment is enabled by market forces, which represent an essential mechanism for resource allocation. It is noteworthy that the NSE also stresses government's facilitating role in the alignment process. Government's main tasks in this regard involve providing and/or upgrading soft and hard infrastructure to reduce transaction costs, compensating pioneer firms for externalities (such as information externalities) and temporarily protecting infant industries, provided that they are consistent with the economy's CAs. The obvious precondition is that the government is aware of the economy's CAs to fulfil its facilitating role effectively.

\section{Growth identification and facilitation framework}

To estimate LCA of a particular economy, it is first necessary to select several appropriate comparator economies. Following the Framework for Growth Identification and Facilitation suggested by Lin and Monga (2011), the selection should be based on three criteria: (1) level of economic development; (2) rate of economic growth; and (3) similarity of ESs.

Firstly, according to Lin and Treichel (2011), per capita GDP in purchasing power parity (PPP) of the appropriate comparator economies should be somewhere between $100 \%$ and $300 \%$ of the reference economy. This is because economic development is a gradual process. LCA of the reference economy may be de facto RCA of the appropriate comparator economies that are slightly more advanced (provided that the following two criteria are met).

Secondly, the appropriate comparator economies should maintain the highest possible GDP growth rate for a long period of time. Lin and Treichel (2011) recommend a yearly average GDP growth rate of at least $6 \%$ for about 20 years. Fulfilling this criterion is essential because, theoretically, rapid and sustained economic growth is a result of the alignment between the industrial structure and the CAs. In other words, rapid economic growth indicates that the CAs are being exploited.

Thirdly, the ESs of the appropriate comparators and of the reference economy should be relatively similar, so that the CAs could also be similar. We compare the ESs using three measures: capital-labour ratio, human capital index and natural capital indicator.

Once the appropriate comparator economies are selected, their RCA can be calculated and compared with those of the reference economy. ${ }^{2}$ The comparison allows for drawing conclusions about LCA in the reference economy because the most common and significant RCA of the appropriate comparator economies in the last 20 years should be theoretically similar for the reference economy. If not, we can argue that the reference economy may possess LCA.

\section{Comparative advantages of Senegal}

Revealed comparative advantage of Senegal (and also appropriate comparator economies - see below), based on the concept of normalised revealed comparative advantage index (NI), was determined as follows. For calculation of the NI index, export data from UNCTAD (2017) have been used. Because we are focusing on manufactured goods only, we incorporated solely the corresponding items, based on UNCTAD (2016) product groupings and composition, that is, SITC groups 5-8, without group 68 (non-ferrous metals) and item 667 (pearls, precious and semi-precious stones). In order to determine long-term state (i.e. long-term RCA), NI index was computed for years 1995, 2000, 2005, 2010 and 2015. As goods manufactured with long-term RCA in a particular economy were considered items that were placed among the top 10, considering the highest NI value, in at least four out of five above mentioned years. Top 10 Senegalese RCA in 2015 are depicted in Table 1. Bolded items represent long-term RCA.

Based on Table 1, the majority of manufactured goods produced and exported from Senegal with the CA is related to chemicals (SITC 5) and manufactured goods classified chiefly by material (SITC 6). To chemicals exported with the long-term RCA belong: inorganic chemical elements (522), perfumery (553), insecticides (591) and soaps (554). Manufactured goods produced and exported with the longterm RCA are lime, cement and fabricated construction materials (661). Obviously, Senegal generally lacks the ability to export manufactured goods with high value added

TABLE 1: Top 10 Senegalese revealed comparative advantage in manufacturing industries (2015).

\begin{tabular}{|c|c|c|}
\hline Article & Volume & NI \\
\hline $\begin{array}{l}\text { [522] Inorganic chemical elements, oxides and halogen } \\
\text { salts† }\end{array}$ & 171279.5 & 0.098345 \\
\hline $\begin{array}{l}\text { [661] Lime, cement, fabrica. constr. mat. (excluding } \\
\text { glass, clay) } \dagger\end{array}$ & 134456.8 & 0.077849 \\
\hline [899] Miscellaneous manufactured articles, n.e.s. & 39423.76 & 0.015149 \\
\hline $\begin{array}{l}\text { [553] Perfumery, cosmetics or toilet prepar. (excluding } \\
\text { soaps) } \dagger\end{array}$ & 23221.34 & 0.006012 \\
\hline [676] Iron and steel bars, rods, angles, shapes and sections & 20537.31 & 0.005271 \\
\hline [611] Leather & 11290,69 & 0.004591 \\
\hline [591] Insecticides and similar products, for retail sale $\dagger$ & 11884.02 & 0.004093 \\
\hline [597] Prepared addit. for miner. oils; lubricat., de-icing & 7671.482 & 0.002539 \\
\hline [554] Soaps, cleansing and polishing preparations $\dagger$ & 8298.832 & 0.001233 \\
\hline [551] Essential oils, perfume and flavour materials & 5405.872 & 0.000698 \\
\hline
\end{tabular}

$\mathrm{NI}$, normalised revealed comparative advantage index

$\dagger$, long-term revealed comparative advantage.

Source: Authors' own calculations, based on: UNCTAD, 2017, 'UNCTADSTAT Database', United Nations Conference on Trade and Development, viewed 26 March 2017, from http:// unctadstat.unctad.org/wds/ ReportFolders/reportFolders.aspx?sCS_ChosenLang=en

2.Originally, Lin (2012) suggests commodity export structures comparisons because . export com period of time represent exploited comparative advantages of the comparator economies and these should be theoretically similar for the reference economy. The GIFF methodology in this paper is, thus, slightly modified. 
or technologically more sophisticated goods. Nonetheless, as Vlčková (2015) points out, that does not necessarily have to indicate a country's low technological capabilities (relative to the achieved level of economic development).

In order to promote industrialisation and growth, Senegal should focus predominantly on the above mentioned industries, where the economy currently enjoys RCA. Furthermore, the identified RCA can serve as a basis for LCA estimation. To estimate LCA, we have to select appropriate comparator economies first. The process of selection is based on the criteria mentioned in the LCA estimation section. Firstly, according to WB (2017), there are 36 developing economies (i.e. low-income, lower-middle income and higher-middle income economies) that have per capita GDP ranging from $100 \%-300 \%$ that of Senegal. Secondly, there are 29 developing countries that achieved at least 6\% average GDP growth rate in the 1995-2015 period (including Tanzania with 5.99\% average GDP growth rate). Combining both indicators leaves us with 10 possible comparator economies for Senegal: Cambodia, Cape Verde, India, Lao PDR, Myanmar, Nigeria, Tanzania, Uzbekistan, Vietnam and West Bank and Gaza (see Table 2). Thirdly, from this set, we have to select the most appropriate comparator economies with relatively similar ESs to that of Senegal. The ESs of the above mentioned economies are depicted in Table 3.

We have gradually removed West Bank, Gaza, Myanmar, Nigeria, Uzbekistan and India from the set. Regarding West Bank and Gaza, we lack required data. Myanmar is unsuitable for CA analysis because of extremely low values of trade openness until 2012 (WB 2017). Nigeria and Uzbekistan are rich in natural capital (see Table 3 ) and both are considered resource-rich economies in IMF (2012) methodology (contrary to Senegal). Finally, India may be comparable to Senegal in relative terms (see Table 3), but not in absolute terms. The sheer size of the Indian economy allows for lower trade openness, specific trade policy, etc.

Therefore, our selection of appropriate comparator economies for Senegal includes: Tanzania, Cambodia, Lao PDR, Vietnam and Cape Verde. ${ }^{3}$ Persistence of their economic growth rates in the last 20 years is displayed in Figure 1. Relatively high persistence, which is definitely desirable for comparator economies, is the characteristic for Lao PDR, Vietnam and Tanzania. On the contrary, Cape Verde exhibits low persistence of economic growth. Regarding the ESs, Lao PDR has an advantage of relative abundance of natural capital (see Table 3), and it is also a resource-rich country (IMF 2012). Nevertheless, we include Lao PDR as one of the comparator economies for two reasons: (1) the relative importance of natural resources in total exports has significantly increased only recently and (2) values of other ES indicators are very similar for both economies (while taking into account differences in per capita GDP). The data on natural capital are not available for Tanzania and Cambodia. While Cambodia is

\footnotetext{
3.Ideally, all the appropriate comparators should be sub-Saharan economies because of regional similarities. However, given the Senegalese level of economic development and endowment structure (see Tables 2 and 3 ), it is not possible development and endowment structure (see Tables 2 and 3 ), it is not possible
because, apart from Cape Verde and Tanzania, there are no other appropriate because, apart from Cape Verde and Tanzania,
comparator economies for Senegal in the region.
}

TABLE 2: Gross domestic product per capita, purchasing power parity (constant 2011 USD) in 2015 and average annual gross domestic product growth rates (1995-2015).

\begin{tabular}{lccc}
\hline Country & $\begin{array}{c}\text { GDP per capita, } \\
\text { PPP (USD) }\end{array}$ & $\begin{array}{c}\text { GDP per capita, PPP } \\
\text { (\% of Senegal) }\end{array}$ & $\begin{array}{c}\text { Average (real) GDP } \\
\text { growth rate (\%) }\end{array}$ \\
\hline Senegal & 2274 & 100 & 4.17 \\
Tanzania & 2510 & 110 & 5.99 \\
Cambodia & 3278 & 141 & 7.7 \\
West Bank and Gaza & 4715 & 207 & 6.25 \\
Myanmar & 4931 & 217 & 9.81 \\
Lao PDR & 5345 & 235 & 7.11 \\
Nigeria & 5639 & 248 & 6.25 \\
Vietnam & 5667 & 249 & 6.77 \\
Uzbekistan & 5717 & 251 & 6.13 \\
India & 5730 & 252 & 6.94 \\
Cape Verde & 6158 & 271 & 7.69 \\
\hline
\end{tabular}

PPP, purchasing power parity; GDP, gross domestic product.

Source: Authors' own calculations, based on: WB, 2017, World development indicators [Online], The World Bank, viewed 21 March 2017, http://data.worldbank.org/data-catalog/ world-development-indicators

TABLE 3: The endowment structures in 2014; (the estimates of natural capital are for the year 2005).

\begin{tabular}{lccc}
\hline Country & $\begin{array}{c}\text { Natural capital (2005 } \\
\text { USD per capita) }\end{array}$ & $\begin{array}{c}\text { Capital-labour } \\
\text { ratio }\end{array}$ & $\begin{array}{c}\text { Human capital } \\
\text { index }\end{array}$ \\
\hline Senegal & 1621 & 23960 & 1.52 \\
Tanzania & $\mathrm{N} / \mathrm{A}$ & 24348 & 1.65 \\
Cambodia & $\mathrm{N} / \mathrm{A}$ & 10383 & 1.82 \\
West Bank and Gaza & $\mathrm{N} / \mathrm{A}$ & $\mathrm{N} / \mathrm{A}$ & $\mathrm{N} / \mathrm{A}$ \\
Myanmar & $\mathrm{N} / \mathrm{A}$ & 13526 & 1.78 \\
Lao PDR & $4444^{*}$ & 31929 & 1.87 \\
Nigeria & 6042 & 34473 & 1.85 \\
Vietnam & 3630 & 27091 & 2.62 \\
Uzbekistan & 7652 & 24136 & $\mathrm{~N} / \mathrm{A}$ \\
India & 2704 & 44077 & 2.05 \\
Cape Verde & 919 & 68098 & $\mathrm{~N} / \mathrm{A}$ \\
\hline
\end{tabular}

Note: Natural capital comprises subsoil assets, pastureland, cropland, timber resources, nontimber forest resources and protected areas. Human capital index is based on years of schooling and returns to education (for more details, see Feenstra et al. 2017). Asterisk indicates that data on subsoil assets are not available and the value of natural capital is, thus, underestimated.

Source: Authors' own calculations, based on: Feenstra, R.C., Inklaar, R. \& Timmer, M.P., 2017, 'The next generation of the penn world table [Online]', American Economic Review 105(10), 3150-3182, viewed 22 March 2017, from http://www.rug.nl/research/ggdc/data/pwt/pwt-9.0

considered resource-poor, Tanzania is among prospective natural resource-exporting economies (IMF 2012). We include Tanzania in the analysis because it is not nearly as dependent on natural resources exports as Nigeria or Uzbekistan. For example, the yearly average of total natural resources rents in Tanzania accounted for 7.4\% of GDP between 1995 and 2015, while Nigeria registered $24.4 \%$ in this period (WB 2017). Furthermore, Cape Verde exhibits a relatively high capitallabour ratio. However, we have to take into account almost three times higher per capita GDP compared to Senegal, which mitigates the difference (see Table 2). Finally, we should also emphasise high levels of human capital in Vietnam. Even though the extent of this problem may be overestimated because of recent data corrections that have significantly changed values of the human capital index (downwards in the case of Senegal and upwards in the case of Vietnam), there is no doubt that Senegal lags behind in this regard. An interesting comparison regarding human capital would be between the two sub-Saharan countries at different levels of per capita GDP, that is, Senegal and Cape Verde, but the required data are not available. In conclusion, the similarity of ESs is by no means ideal. However, one can 


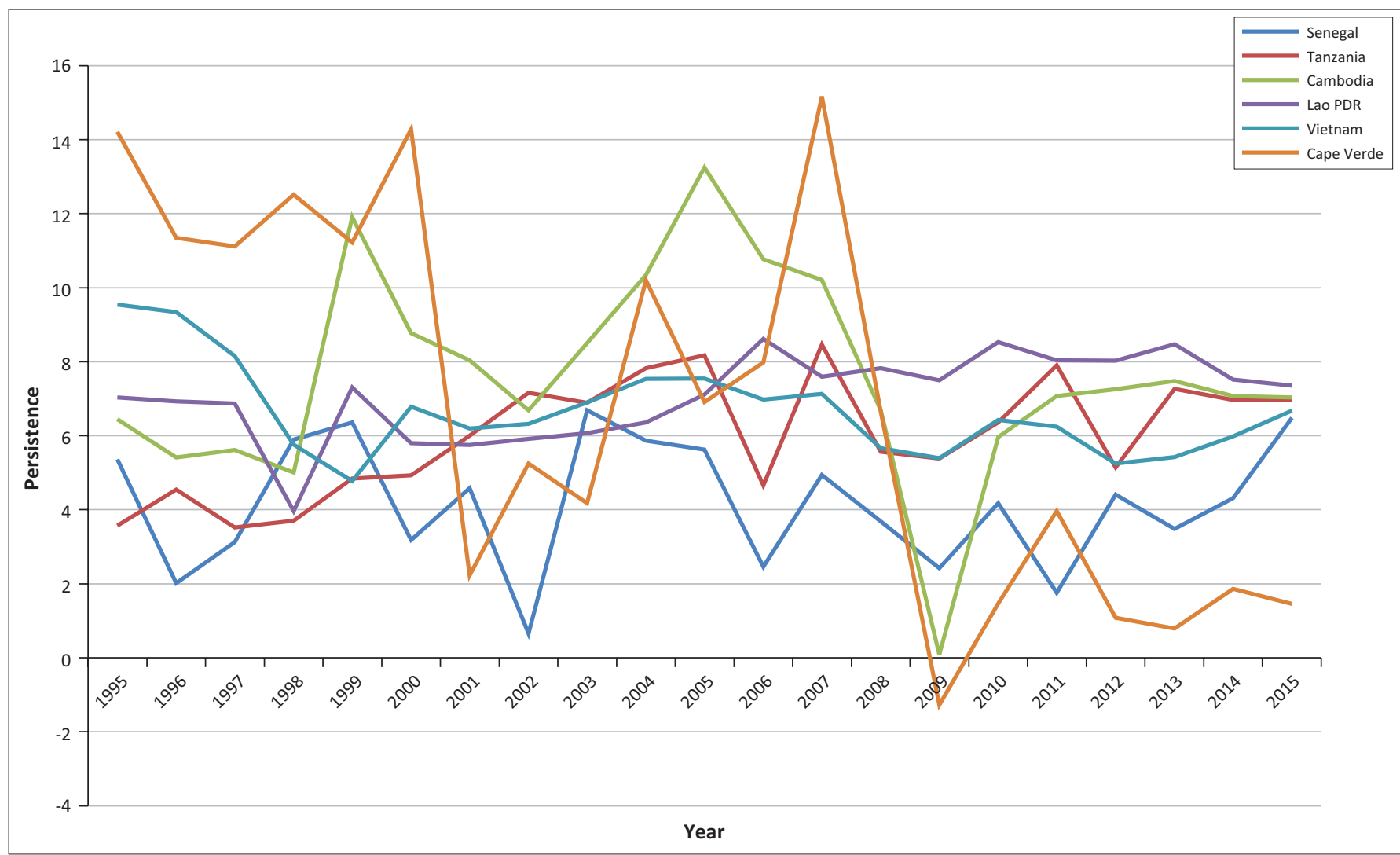

Source: Authors' own calculations, based on: WB, 2017, World development indicators [Online], The World Bank, viewed 21 March 2017, http://data.worldbank.org/datacatalog/world-development-indicators

FIGURE 1: Persistence of gross domestic product growth in Senegal and appropriate comparator economies (1995-2015; in percentage).

hardly find better comparator economies for Senegal given its current stage of development and endowment structure.

To estimate Senegalese LCA in manufacturing industries, we have calculated and compared the most significant long-term RCA (i.e. RCA that were among top 10 in at least four out of the following five years: 1995, 2000, 2005, 2010 and 2015) of Senegal and all five comparator economies. Results of the comparisons are depicted in Table 4. Bolded items represent matches in long-term RCA of at least two comparator economies. It is apparent from the comparison that four out of five comparator economies have long-term RCA in men's clothing of textile fabrics, not knitted [841], three comparator economies exhibit long-term RCA in footwear [851] and articles of apparel, of textile fabrics, n. e. s. [845] and two comparator economies demonstrate long-term RCA in women's clothing [842, 844] and men's or boy's clothing [843]. In conclusion, except for Tanzania, all other comparator economies have RCA in the apparel industry. Moreover, Cambodia, Vietnam and Cape Verde have also RCA in the footwear industry. Surprisingly though, according to the UNCTAD (2017) database, Senegalese apparel and footwear exports were virtually non-existent in the last 20 years. We therefore argue that Senegal may have LCA in footwear and particularly in apparel production.

According to the theory, we can assume that there are: (1) infrastructural deficiencies and other constraints that prevent Senegalese apparel and footwear industries from improving competitiveness and (2) some barriers that may restrict
Senegalese entrepreneurs from entering those industries (Lin \& Monga 2011). The deficiencies, constraints and barriers must be identified and addressed by the government. But first it is necessary to conduct an additional detailed value chain analysis of the above identified industries to corroborate the findings (Lin \& Treichel 2011). However, such analysis goes beyond the scope of this paper. Nevertheless, we can enquire into the apparel industry in Senegal to shed some light on the most common problems that local entrepreneurs face.

\section{Discussion: Some challenges in Senegalese apparel industry}

Generally, Senegalese entrepreneurs are mostly engaged in the informal sector activities (Khadidiatou et al. 2014). Apparel industry is not an exception in this regard. Golub and Mbaye (2002) note:

Virtually all large scale apparel production in Senegal ceased in the 1980s. The market now consists of a booming informal sector composed of independent tailors working on their own or in small shops. (p. 7)

The existence of a large informal sector is a big problem for government. First of all, it is extremely hard to effectively collect useful data from decentralised and unorganised entrepreneurs in an informal economy. Therefore, the government, for example, is not able to assess key infrastructural deficiencies and constraints that Senegalese entrepreneurs in the apparel industry face. Under such circumstances, it is very challenging to develop and implement effective industrial policy. 
TABLE 4: Long-term RCA of Senegal and comparator economies in manufacturing industries (RCA among top 10 in at least four out of following five years: 1995 2000, 2005, 2010 and 2015).

\begin{tabular}{|c|c|}
\hline Country & Article \\
\hline Senegal & $\begin{array}{l}\text { [522] Inorganic chemical elements ... } \\
\text { [553] Perfumery, cosmetics ... } \\
\text { [591] Insecticides and similar products ... } \\
\text { [661] Lime, cement, fabrica. ... } \\
\text { [554] Soaps, cleansing prep.... }\end{array}$ \\
\hline Tanzania & $\begin{array}{l}\text { [532] Dyeing and tanning extracts ... } \\
\text { [665] Glassware } \\
\text { [661] Lime, cement, fabrica. ...\$ } \\
\text { [657] Special yarn ... }\end{array}$ \\
\hline Cambodia & $\begin{array}{l}\text { [845] Articles of apparel ...† } \\
\text { [841] Men's clothing ...† } \\
\text { [842] Women's clothing ...† } \\
\text { [844] Women's clothing ...† } \\
\text { [843] Men's or boy's clothing ...† } \\
\text { [851] Footwear } \dagger\end{array}$ \\
\hline Lao & $\begin{array}{l}\text { [841] Men's clothing ...† } \\
\text { [845] Articles of apparel ...† } \\
\text { [843] Men's or boy's clothing ...† } \\
\text { [844] Women's clothing ...† }\end{array}$ \\
\hline Vietnam & $\begin{array}{l}\text { [851] Footwear } \dagger \\
\text { [841] Men's clothing ...† } \\
\text { [845] Articles of apparel ...† } \\
\text { [842] Women's clothing ...† } \\
\text { [821] Furniture and parts } \ddagger\end{array}$ \\
\hline Cape Verde & $\begin{array}{l}\text { [851] Footwear } \dagger \\
\text { [841] Men's clothing ...† } \\
\text { [793] Ships, boats ... } \$ \\
\text { [786] Trailers and semi-trailers } \$\end{array}$ \\
\hline
\end{tabular}

Source: UNCTAD (2017), own calculations

$\dagger$, match in long-term RCA of at least two comparator economies; $\ddagger$ RCA among top 10 precisely in four out of five observed years.

Existing literature offers at least some information (usually survey- or questionnaire-based) on those deficiencies and constraints in the Senegalese apparel industry, which may provide basic guidelines for possible government interventions. The most frequent problems include: poor access to financing; unreliable electricity supply; high cost of electricity; and fierce competition from abroad including imports of second-hand clothing and illegal imports (ACET 2014). Moreover, these problems seem to be pervasive (Golub \& Mbaye 2002). The government, thus, needs to tackle them systematically in order to facilitate the alignment process. Furthermore, it should be noted that, according to available data, wages in Senegalese manufacturing industries appear to be relatively high given the country's per capita GDP (Ceglowski et al. 2015). Other constraints arise from contemporary characteristics of global apparel production. Because global value chains (GVC) are concentrated in this industry (ACET 2014), Senegalese producers would need to enter them in order to take part in large scale exports. This poses yet another challenge, especially with regard to cost/quality/time requirements.

The competition in a global market is tough. However, according to Lin (2012), the most successful and competitive economies grow rapidly, and their ESs and CAs change over time. This process creates opportunities for catch-up in less developed economies. Nowadays, a sizeable opportunity arises because the People's Republic of China is slowly losing its CAs in labour intensive industries such as apparel and footwear (Chandra et al. 2012). Considering the fact that in 2015, China alone exported apparel worth 174 billion USD (37\% of global apparel exports), the opportunity seems really promising (UNCTAD 2017). Actually, some footloose industrial enterprises have already been relocated, either to inland provinces or abroad. The trend will most likely continue accordingly to the so called flying geese pattern (Chandra et al. 2012; Ruan \& Zhang 2014). Therefore, under certain circumstances, Senegal might be able to attract some apparel manufacturers from China. There are, however, many more competitors.

To the contrary, Senegal possesses several country-specific advantages, such as easy access to the Atlantic Ocean, relative proximity of rich markets (EU and USA) or availability of key inputs for production (cotton, leather). In addition, Senegalese exporters do not suffer from major trade barriers, thanks to preferential trade agreements (most notably the Everything But Arms initiative and African Growth and Opportunity Act). Senegal is also an Economic Community of West African States (ECOWAS) member state. Nevertheless, as Lin and Monga (2011) argue, potential success of exploiting the identified LCA depends on the government's ability to implement policies to facilitate the alignment process.

\section{Conclusion}

Using the concept of RCA and LCA, the aim of this paper was to identify productive industries and industries with great potential in the Senegalese economy. The analysis was focused on manufacturing industries becauseindustrialisation serves as an engine of growth in developing countries.

Regarding RCA (based on the concept of normalised revealed comparative advantage index), our results indicate that Senegalese production and exports with the RCA are mostly concentrated in industries related to chemicals (e.g. inorganic chemical elements, perfumery, etc.) and manufactured goods classified chiefly by material (e.g. lime, cement and fabricated construction materials). To estimate LCA (based on the Framework for Growth Identification and Facilitation), we selected five appropriate comparator economies: Tanzania, Cambodia, Lao PDR, Vietnam and Cape Verde. The comparison of their long-term RCA with the Senegalese suggests that Senegal may have LCA in footwear and particularly in the apparel industry. However, the estimation should be further tested in a detailed value chain analysis of the identified industries.

In conclusion, Senegal could accelerate its rate of economic growth by aligning its economic structure with the identified CAs. In particular, competitive apparel and footwear industries are undeveloped and may present great potential given the contemporary characteristics of the Senegalese economy. Finally, it should be emphasised that the government's role in the alignment process is to facilitate it by proper interventions (e.g. by providing relevant soft and hard infrastructure). In this regard, one of the most 
challenging tasks for the government entails gathering relevant information about infrastructural deficiencies and other constraints that present obstacles for Senegalese entrepreneurs. For example, existing information from informal apparel industry suggests that entrepreneurs are struggling because of poor access to financing; unreliable electricity supply; high cost of electricity; and fierce competition from abroad including imports of second-hand clothing and illegal imports. These challenges should be at the top of the government's priority list.

\section{Acknowledgements}

This article was created with the support of the IGA project: The impact of growing global middle class on selected developing and developed regions, No. F2/47/2016. Earlier versions of parts of this article were presented at the MAC-EMM 2015 Multidisciplinary Academic Conference on Economics, Management and Marketing in Prague 2015 and at the International Academic Research Conference on Small \& Medium Enterprises in Danang City 2016, respectively. We gratefully acknowledge two anonymous reviewers for their insightful comments.

\section{Competing interests}

The authors declare that they have no financial or personal relationship(s) that may have inappropriately influenced them in writing this article.

\section{Authors' contributions}

The authors, J.S. and O.S., contributed equally to the writing of this article.

\section{References}

ACET, 2014, African transformation report: Growth with depth [Online.], African Center for Economic Transformation, viewed 05 April 2017, from http:// africantransformation.org/wp-content/uploads/2014/02/2014-africantransformation-report.pdf

Balassa, B., 1965, 'Trade liberalization and revealed comparative advantage', The Manchester School of Economic and Social Studies, 33, 99-124. https://doi. org/10.1111/j.1467-9957.1965.tb00050.x

Balance, R.H., Forstner, H. \& Murray, T., 1987, 'Consistency tests of alternative measures of comparative advantage', Review of Economics \& Statistics 69(1), 157-161. https://doi.org/10.2307/1937915

Ceglowski, J., Golub, S., Mbaye, A. \& Prasad, V., 2015, Can Africa compete with China in manufacturing? The role of relative unit labor costs [Online], University of Cape
Town's Development Policy Research Unit, viewed 04 April 2017, from http:// www.swarthmore.edu/sites/default/files/assets/documents/user_profiles/ www.swarthmore.edu/sites/default/files/assets/docume
sgolub1/China-Africa\%20Competitiveness.feb\%2021.pdf

Chandra, V., Lin, J.F. \& Wang, Y., 2012, Leading dragons phenomenon: New opportunities for catch-up in low-income countries [Online], Policy Research opportunities for catch-up in low-income countries [Online], Policy Research
Working Paper 6000, No. 1, pp. 1-58, viewed 04 April 2017, from http://elibrary. Working Paper 6000, No. 1, pp. 1-58, viewed 04 Apris
worldbank.org/doi/pdf/10.1596/1813-9450-6000

Clarida, R.H. \& Findlay, R., 1992, 'Government, trade and comparative advantage', American Economic Review 82(2), 122-127.

Deardorff, A.V., 1980, 'The general validity of the law of comparative advantage', Journal of Political Economy 88(5), 941-957. https://doi.org/10.1086/260915

Deardorff, A.V., 2011, 'Comparative advantage: The theory behind measurement [Online]', Globalization, comparative advantage and the changing dynamics of trade, OECD Publishing, pp. 27-39. https://doi.org/10.1787/9789264113084-en

Dong, G., Dall'erba, S. \& Le Gallo, J., 2013, 'The leading role of manufacturing in China's regional economic growth: A spatial econometric approach of Kaldor's laws', International Regional Science Review 36(2), 139-166. https://doi. org/10.1177/0160017612457779

Drabicki, J.Z. \& Takayama, A., 1979, 'An antinomy in the theory of comparative advantage', Journal of International Economics 9(2), 211-223. https://doi. org/10.1016/0022-1996(79)90004-7
Eifert, B., Gelb, A. \& Ramachandran, V., 2005, Business environment and comparative advantage in Africa: Evidence from the investment climate data [Online], Center for Global Development Working Paper No. 56, viewed 05 April 2017, from https://www.cgdev.org/files/2732_file_WP56_1_revis.pdf

Feenstra, R.C., Inklaar, R. \& Timmer, M.P., 2017, 'The next generation of the penn world table [Online]', American Economic Review 105(10), 3150-3182, viewed 22 March 2017, from http://www.rug.nl/research/ggdc/data/pwt/pwt-9.0

Golub, S. \& Mbaye, A., 2002, Obstacles and opportunities for Senegal's international competitiveness: Case studies of the peanut oil, fishing and textile industries [Online], Africa Region Working Paper Series, No. 37, pp. 1-42, viewed 05 April 2017, from https://pdfs.semanticscholar.org/e611/2bb11b540ae296c679b7827c 6bfd725ee16f.pdf

Hillman, A.L., 1980, 'Observations on the relation between "Revealed comparative advantage" and comparative advantage as indicated by pre-trade relative prices', Review of World Economics (Weltwirtschaftliches Archiv) 116(2), 315-321. https://doi.org/10.1007/bf02696859

Hoen, A. \& Oosterhaven, J., 2006, 'On the measurement of comparative advantage', Annals of Regional Science 40(3), 677-691. https://doi.org/10.1007/s00168-0060076-4

Ibbih, J.M. \& Gaiya, B.A., 2013, 'A cross-sectional analysis of industrialization and growth in Africa', International Research Journal of Arts and Social Sciences 2(6) 150-167, viewed 29 July 2016, from http://www.interesjournals.org/irjass/july2013-vol-2-issue-6/a-cross-sectional-analysis-of-industrialization-and-growth-inafrica

IMF, 2012, 'Macroeconomic policy frameworks for resource-rich developing countries', International Monetary Fund, viewed 25 July 2016, from http://www. imf.org/external/np/pp/eng/2012/082412.pdf

Infodev, 2011, The Agribusiness Innovation Center of Senegal: Scaling a competitive horticulture sector through value adding post-harvest processing, InfoDev, Finance and Private Sector Development Department, World Bank, Washington, DC, viewed 05 April 2016, from http://documents.worldbank.org/curated/ en/205731468306285036/pdf/840040WPOBox380senegal00OfullOstudy.pdf

Irwin, D., 1991, 'Retrospectives: Challenges to free trade', Journal of Economic Perspectives 5(2), 201-208. https://doi.org/10.1257/jep.5.2.201

Jabara, C.L. \& Thompson, R.L., 1980, 'Agricultural comparative advantage under international price uncertainty: The case of Senegal', American Journal of Agricultural Economics 62(2), 188-198. https://doi.org/10.2307/1239684

Kaldor, N., 1966, Causes of the slow rate of growth of the United Kingdom, Cambridge University Press, Cambridge.

Kaldor, N., 1967, Strategic factors in economic development, New York State School of Industrial and labour Relations, Cornell University, Ithaca, NY.

Khadidiatou, G., Toussaint, H. \& Bakary T., 2014, 'Senegal', African Economic Outlook viewed 25 July 2016, from http://www.africaneconomicoutlook.org/fileadmin/ uploads/aeo/2014/PDF/CN_Long_EN/Senegal_EN.pdf

Kuznets, S., 1966, Modern economic growth: Rate, structure and spread, Yale University Press, New Haven, CT.

Libanio, G. \& Moro, S., 2006, 'Manufacturing industry and economic growth in Latin America: A Kaldorian approach', in Second Annual Conference for Development and Change, Campos Do Jordão, Brazil, viewed 29 July 2016, from http://www. networkideas.org/networkideas/editorfiles/file/Gilberto_Libanio.pdf

Lin, J.Y., 2012, New structural economics: A framework for rethinking development and policy, The World Bank, Washington, DC, ISBN 978-0-8213-8957-7, viewed 30 July 2016, from http://siteresources.worldbank.org/DEC/Resources/847971104785060319/598886-1104951889260/NSE-Book.pdf

Lin, J.Y. \& Monga, C., 2011, 'Growth identification and facilitation: The role of the State in the dynamics of structural change', Development Policy Review 29(3), 259-310. https://doi.org/10.1111/j.1467-7679.2011.00534.x

Lin, J.Y. \& Treichel, V., 2011, 'Applying the growth identification and facilitation framework: The case of Nigeria', Policy Research Working Paper 5776, vol. 1, pp. frame viewed 30 July 2016, from http://elibrary.worldbank.org/doi/ 1-44, viewed 30 July
pdf/10.1596/1813-9450-5776

Lin, J.Y. \& Xu, J., 2015, 'Applying the growth identification and facilitation framework (GIFF) to the least-developed countries (LDCs): The case of Uganda', Working Paper for the UN DESA Capacity-building Workshop, Geneva, 03-06 November 2015, viewed 30 July 2016, from http://esango.un.org//dcportal/documents/10191/ 14587/Applying\%20the $\% 20$ GIFF\%20to $\% 20$ the $\% 20$ case $\% 20$ of $\% 20$ Uganda.pdf

Memedovic, O., 1994, On the theory and measurement of comparative advantage: An empirical analysis of Yugoslav trade in manufactures with the OECD countries 1970-1986, Tinbergen Institute Research Series, Thesis Pub, Amsterdam.

Ricardo, D., 1815, Essay on the influence of a low price of corn on the profits of stock, John Murray, London.

Ruan, J. \& Zhang, X., 2014, “"Flying geese” in China: The textile and apparel industry's pattern of migration', Journal of Asian Economics 34, 79-91. https://doi. org/10.1016/j.asieco.2014.06.003

Sanidas, E. \& Shin, Y., 2010, Comparison of revealed comparative advantage indices with application to trade tendencies of East Asian Countries, Department of Economics, Seoul National University, viewed 23 July 2016, from http://www. akes.or.kr/eng/papers(2010)/24.full.pdf

UNCTAD, 2016, 'UNCTAD product groupings and composition', in United Nations Conference on Trade and Development, viewed 04 April 2017, from http:// unctadstat.unctad.org/EN/Classifications/DimSitcRev3Products_DsibSpecial Groupings_Hierarchy.pdf

UNCTAD, 2017, 'UNCTADSTAT Database', United Nations Conference on Trade and Development, viewed 26 March 2017, from http://unctadstat.unctad.org/wds/ ReportFolders/reportFolders.aspx?sCS_ChosenLang=en 
Vlčková, J., 2015, 'Can exports be used as an indicator of technological capabilities of countries?', Geography: Journal of Czech Geographical Society 120(3), 314-329. countries?, Geogr $1212-0014$.
ISSN

Vollrath, T., 1991, 'A theoretical evaluation of alternative trade intensity measures of revealed comparative advantage', Weltwirtschaftliches Archiv 127(2), 265-280. https://doi.org/10.1007/BF02707986

WB, 2011, The changing wealth of nations: Measuring sustainable development in the New Millennium [Online], The World Bank, viewed 10 August 2016, from http://siteresources.worldbank.org/ENVIRONMENT/Resources/ChangingWealth Nations.pdf

WB, 2017, World development indicators [Online], The World Bank, viewed 21 March 2017, http://data.worldbank.org/data-catalog/world-developmentindicators
Wells, H. \& Thirwall, A.P., 2003, 'Testing Kaldor's growth laws across the countries of Africa', African Development Review 15(2-3), 89-105. https://doi.org/10.1111/j. 1467-8268.2003.00066.x

Yeats, A., 1985, 'On the appropriate interpretation of the revealed comparative advantage index: Implications of a methodology based on industry sector analysis', Weltwirtschaftliches Archiv 121(1), 61-73. https://doi.org/10.1007/ BF02705840

Yeats, A., 1998, 'What can be expected from African regional trade arrangements? Some empirical evidence', in World Bank Policy Research Working Paper No. 2004 Trade, Development Research Group, The World Bank, Washington, DC.

Yu, R., Cai, J. \& Leung, P., 2009, 'The normalized revealed comparative advantage index', The Annals of Regional Science 43(1), 267-282. https://doi.org/10.1007/ s00168-008-0213-3 